\title{
Evaluation of the Use of Carbon Isotope Discrimination as a Selection Tool of Perennial Fodder Species for Temporary Pastures
}

\author{
Nicuşor-Flavius SIMA , Rodica Maria SIMA*, Stela CUNA², Gabriela CRISTEA², Valentin MIHAI \\ ${ }^{1}$ University of Agricultural Sciences and Veterinary Medicine, 3-5 Mănăştur Street, 400372, Cluj- \\ Napoca,Romania; rodiganea@yahoo.com (*correspondingauthor) \\ ${ }^{2}$ National Institute for Research and Development of Isotopic and Molecular Technologies, 65-103 Donath Street, 400293, Cluj-Napoca, Romania
}

\begin{abstract}
Estimation of the relationship between carbon isotope discrimination $\left(\Delta^{13} \mathrm{C}\right)$ in perennial fodder plants and various factors such as climate, fertilization and soil could contribute to a better selection and/or improvement of genotype of fodder species. Theoretical models of carbon isotope discrimination in plants indicate a linear relationship between $\Delta^{13} \mathrm{C}$ and $\mathrm{CO}_{2}$ partial pressures ratio $\left(p_{i} / p_{a}\right)$ from the intercellular spaces $\left(p_{i}\right)$ of $\mathrm{CO}_{2}$ in leaves and from the atmosphere $\left(p_{a}\right)$. It is also known that between $p_{i}$ parameter and wateruse efficiency (WUE) there is a negative correlation. Eight perennial fodder legume and grass mixtures were cultivated on three levels of fertilization in order to assess mixtures for pastures that can provide sustainable quantitative and qualitative yields. The species, which composed the mixtures, were also cultivated as pure crops on the same fertilization conditions. The results of this study indicated that in five of the six species, which composed the mixture with the highest yield, $p_{i} / p_{a}$ values decreased while fertilization doses increased, most likely as a result of variation in water-use efficiency.
\end{abstract}

Keywords: isotope composition, mixture, neutral detergent fiber, sown pasture, yield

\section{Introduction}

European Commission working documents, with respect to the impact of agriculture on climate change (Commission of the EC, 2009), revealed that the net $\mathrm{CO}_{2}$ emissions reached 57 million tons in 2007 for EU agricultural lands. Arable lands were known to be net sources for $\mathrm{CO}_{2}$ emissions, with 70 million tons, while pastures' net $\mathrm{CO}_{2}$ storage sources were 13 million tons. Therefore, it is depicted that the increase of the $\mathrm{CO}_{2}$ concentration in the atmosphere will lead to a series of climate changes, including the shift in the annual and seasonal rainfalls and temperature regime, as well as the change in the frequency of extreme conditions, such as drought and floods. These extreme conditions would exert their influence on the quality, quantity and stability of agricultural production. The effects of such extreme conditions such as drought, on agricultural production have already been felt in Europe (Hopkins and Del Prado, 2007). For Romania, however, climate scenarios within the National strategy on the reduction of drought effect have indicated a decrease in summer rainfall levels (MARD, 2008). This deficit will affect the most vulnerable crop plants, such as cereal grains and extensive crop plants. Considering these forecasts, the working commissions for agriculture and climate change within the EC drafted a series of recommendations for employing certain crops and varieties that are better adapted to the new humidity and temperature conditions (Euro- pean Commission of the EC, 2009). Similarly, The United Nations Framework Conventions on Climate Change (UNFCCC, 1992) encouraged research for adapting agricultural exploitations to the new climate change. For animal breeders, the aim is to set up temporary pastures with complex perennial grasses and legume mixtures alongside annual fodder crops, as the means to adapt their exploitation to present-day and future climate conditions.

In order to ensure the biodiversity of pasture systems, as well as for sustainable fodder production, the complex mixtures are recommended. The moderate increase of the number of species in pasture ecosystems leads to an increase of the availability of nutritive resources due to their more productive employment (Connolly et al., 2009). In the case of temporary pastures, the selection of complex mixtures of species adapted to certain ecologic conditions and the employment of moderate fertilization doses may minimize the negative effect of soil water deficit on fodder production (Surault et al., 2007). Thus, the need to raise awareness among farmers with respect to the multifunctional dimension of pastures is paramount, alongside the emphasis on economic and environmental benefits intrinsic to the pasture (Beranger, 2002; Carlier et al., 2009; Lehmann and Hediger, 2004; Nyfeler et al., 2009). A progress for Romanian farmers in this respect was taken once complex mixtures for temporary pastures (of more than three species) were standardized. These mixtures would include grasses and perennial fodder legumes 
in accordance with certain ecologic conditions, harvest method (mowing, grazing or mixed) and crop technologies (Motcă et al., 1994). The requirement to verify the importance of mixtures and making the necessary adjustments to restandardize them is of utmost importance in relation to present climate change, as well as scientific progress in breeding and genetic engineering to obtain new cultivars (Carlier et al., 2009; Mosimann et al., 2008; Pannecoucque et al., 2011; Van Waes et al., 2008). In the selection of fodder species, namely genotypes employed in pasture mixtures, one should consider plant traits, such as production and fodder value, as well as their capacity for efficient water use within certain ecologic and technologic conditions. A solution in this respect resides in the capitalization of the carbon isotope discrimination in perennial fodder plants (Grieu et al., 2001). The knowledge on the carbon isotope discrimination in fodder plants can lead to a better understanding of water use efficiency (WUE), an important parameter for fodder production on farms. The WUE indicator expressed by the fodder production obtained for a water unit applied through irrigation is regularly employed as a good practice benchmark in irrigation use. This indicator is available to dairy farmers and allows them to assess their irrigation performance (Neal et al., 2011), as well as partially forecast the sustainability of farm fodder production.

\section{Materials and methods}

The research was conducted in 2010 on the field of the Teaching and Research Station Cojocna of the University of Agricultural Sciences and Veterinary Medicine of ClujNapoca, in a northern-oriented location (46.26'22.6" $\mathrm{N}$ and $23^{\circ} 32^{\prime} 19.7^{\prime \prime} \mathrm{E}$ ), and an altitude of $353.9 \mathrm{~m}$ a.s.l. Soil in the experimental field is luvic phaeozem. The results of soil analyses for samples collected at a $0-10 \mathrm{~cm}$ depth indicated a neutral reaction, a good total nitrogen and potassium supply and a very good phosphorus supply. The experiment was bifactorial (species/mixture with 9 graduations and fertilization with 3 graduations) and was organized according to the subdivided plots method. The 27 variants were placed in 3 replications. The species/ mixtures under study included the following legumes and grasses in the sowing mixture (\%): M1. Medicago sativa $\mathrm{L}$. - control; M2. Medicago sativa L., Trifolium alexandrinum L., Dactylis glomerata L., Lolium x hybridum Hausskn. (40\% grasses and 60\% legumes); M3. Lotus corniculatus L., Onobrychis viciifolia Scop., Dactylis glomerata L., Festuca pratensis Huds., Bromus inermis Leyss. (53\% grasses and $47 \%$ legumes); M4. Medicago sativa L., Dactylis glomerata L., Festuca arundinacea Schreb., Lolium perenne L. (70\% grasses and 30\% legumes); M5. Trifolium pratense L., Dactylis glomerata L., Festulolium Asch. and Graebn., Phleum pratense L., Lolium perenne L. (85\% grasses and 15\% legumes); M6. Lotus corniculatus L., Phleum pratense L., Dactylis glomerata L., Festuca arundinacea Schreb.,
Festuca pratensis Huds. (85\% grasses and 15\% legumes); M7. Trifolium pratense L., Lotus corniculatus L., Trifolium alexandrinum L., Dactylis glomerata L., Festuca pratensis Huds., Lolium $x$ hybridum Hausskn. (70\% grasses and $30 \%$ legumes); M8. Trifolium pratense L., Trifolium repens L., Dactylis glomerata L., Festuca pratensis Huds., Phleum pratense L., Lolium x hybridum Hausskn., Lolium perenne L. (78\% grasses and 22\% legumes); M9. Medicago sativa L., Trifolium repens L., Bromus inermis Leyss., Festuca arundinacea Schreb., Lolium $x$ bybridum Hauskn. (76\% grasses and $24 \%$ legumes). The scientific names of species are in accordance with the employed nomenclature of Romanian flora (Ciocârlan, 2000) and the Food and Agriculture Organization (FAO, grassland index). Each plot $\left(27 \mathrm{~m}^{2}\right)$ was subdivided according to three levels of fertilization $\left(\mathrm{F} 1-0 \mathrm{~N} 0 \mathrm{P}_{2} \mathrm{O}_{5}, \mathrm{~F} 2-60 \mathrm{~N} 70 \mathrm{P}_{2} \mathrm{O}_{5}, \mathrm{~F} 3-120 \mathrm{~N} \mathrm{OP} \mathrm{P}_{2} \mathrm{O}_{5}\right.$ $\left.\mathrm{kg} \cdot h \mathrm{a}^{-1} \cdot \mathrm{y}^{-1}\right)$.

All species in the mixtures were cultivated as pure crops according to the same three fertilization levels. The first year of vegetation (2010) was also the first year of production. Throughout the growing period, three cuttings were harvested. Each harvesting cycle was triggered at the heading-beginning of the flowering phenophase of legumes. After the second cutting, crop fertilization was conducted according to the experimental protocol. The fresh matter (FM) yield and the flower composition were gravimetrically determined. The fresh matter yield was determined by harvesting and weighing the vegetal matter at the surface of each variant $\left(9 \mathrm{~m}^{2}\right)$. There were 200 $\mathrm{g}$ samples collected and dried in a drying oven, at a $60^{\circ} \mathrm{C}$, for $48 \mathrm{~h}$ to determine the dry matter (DM) yield. Botanical composition of sward of each variant was analyzed in samples of $500 \mathrm{~g}$ of harvested fresh matter. Each sample was separated according to three economic plant groups (grasses, legumes and weeds), followed by the weighing of each group. Quality assessment of the third cutting fodder was assessed by analysis for the crude protein (CP) content, through the Kjeldahl method and the cell wall matrix (neutral detergent fiber-NDF, acid detergent fiber$\mathrm{ADF}$ and acid detergent lignin-ADL), using the Van Soest method (Van Soest, 1982).

In order to determinate $\Delta^{13} \mathrm{C}$ it was taken into consideration that atmospheric carbon contains two stable isotopes, namely ${ }^{13} \mathrm{C}(1.11 \%)$ and ${ }^{12} \mathrm{C}(98.89 \%)$. Although plants assimilate $\mathrm{CO}_{2}$ from the atmosphere, they appear to be depleted of the ${ }^{13} \mathrm{C}$ isotope in relation to the air isotope ( $\delta \mathrm{a}$ ) composition (Farineau and Morot-Gaudry, 2006). The differences in the ${ }^{13} \mathrm{C}$ content in plant tissues in relation to air are low, often under $1 \%$. The ${ }^{13} \mathrm{C}$ scarcity in plants compared to atmospheric $\mathrm{CO}_{2}$ is due to the isotope fractions that occur during diffusion in leaves and during $\mathrm{CO}_{2}$ fixation through photosynthesis (Farineau and Morot-Gaudry, 2006). The effects of diffusion are integrated into discrimination, hence determining a simple and positive relationship between discrimination and the 
36

partial pressure ratio of $\mathrm{CO}_{2}$ in intercellular spaces and atmosphere $\left(p_{i} / p_{a}\right)$ (Farquhar et al., 1982).

For the $3^{\text {rd }}$ cutting field measurements were performed to establish the $\mathrm{CO}_{2}$ (ppm) air concentration at a $1 \mathrm{~m}$ height from the soil surface, as well as at a $0.25 \mathrm{~m}$ height, where the leaves were collected. Leaf samples were collected for cultivated species as pure crops, in accordance with each fertilization level. The $\mathrm{CO}_{2}$ measurements were conducted with a portable EGM-4 Environmental Gas infrared analyzer and an average value was set for the air concentration of $\mathrm{CO}_{2}$ employed by plants for photosynthesis $(364.4 \mathrm{ppm})$. The measurements on the isotope plant composition $(\delta \mathrm{p})$ were determined through the mass spectrometry technique with a Delta V Advantage Thermo Finnigan mass spectrometer. For this analysis samples were dried immediately following collection at $70^{\circ} \mathrm{C}$ for $24 \mathrm{~h}$ and ground until they reached a particle size of 0.3 $\mathrm{mm}$ and then combusted in oxygen excess to achieve the conversion of organic carbon of leaves in $\mathrm{CO}_{2}$.

Thus, to determine the $\Delta^{13} \mathrm{C}$ and the partial pressure ratio, it was considered that the plant species under experiment exhibit C3 type photosynthesis (Brugnoli and Farquhar, 1995). The definition of carbon isotope discrimination is provided as follows, and employed in the estimation of intercellular partial pressures (Coleman, 1991):

$\Delta=\mathrm{R}_{\mathrm{a}} / \mathrm{R}_{\mathrm{p}}-1$ (1), where:

$\delta_{\mathrm{a}}=\mathrm{R}_{\mathrm{a}}^{\mathrm{a}} / \mathrm{R}_{\mathrm{S}}^{\mathrm{p}}-1$, for $\mathrm{CO}_{2}$ in the air (2);

$\delta_{\mathrm{p}}^{\mathrm{a}}=\mathrm{R}_{\mathrm{p}}^{\mathrm{a}} / \mathrm{R}_{\mathrm{s}}-1$, for the plant material (3);

while $\delta_{a}$ and $\delta_{p}$ represent the relative variations of carbon isotope ratios and $R_{a}, R_{p}$, and $R_{S}$ are the molar abundance ratio $\left({ }^{13} \mathrm{C} /{ }^{12} \mathrm{C}\right)$ in the air, plant and standard (standard for carbon has been considered Pee Dee belemnite). After extraction of $R_{a}$ and $R_{p}$ parameters from equations (2) and (3) and their substitution in equation (1), equation (1) becomes:

$$
\Delta=\frac{\delta_{a}-\delta_{p}}{1+\delta_{p}}
$$

Carbon isotope discrimination has allowed for the calculus of the $p_{i}$ parameter, followed by the partial pressure ratio making use if the Farquhar relation (Farquhar et al., 1982):

$$
\Delta=a+(b-a) \frac{p_{i}}{p_{a}}
$$

where:

$p_{d} p_{i}$ are partial $\mathrm{CO}_{2}$ pressures in the atmosphere and intercellular leaf spaces;

$a$ is the isotope fraction of carbon that occurs during air diffusion (4.4\%o);

$b$ is the net isotope discrimination of carbon due to the carboxylation of $\mathrm{C}_{3}$ plants and is generally set at $30 \%$.

The DM yields were statistically analyzed by Duncan test, using M1 variant (pure alfalfa crop) as control.

\section{Results and discussions}

This study presents the results of research on the selection of complex mixtures of perennial fodder plants for temporary pastures in the Transylvanian Plain. In this respect, agronomic information was employed, as well as data on $\Delta^{13} \mathrm{C}$ for perennial fodder species.

The influence of the mixture factor in the fodder harvest was analyzed relying on the dry matter yields obtained for each variant and each of the three cuttings. All tested mixtures provided larger yields compared to the alfalfa monoculture (Tab. 1). Yield results obtained within the Cojocna ecologic conditions confirm the superiority of mixtures compared to the monoculture like in previous studies (Skinner et al., 2004; Skinner et al., 2006) as mixtures M7, M2, M8, M5 and M9 had significant yield increases compared to the pure alfalfa crop. The highest yield (17.48 tha $\left.{ }^{-1} \mathrm{DM}\right)$ was obtained by the M7 mixture of 6 species ( 3 grasses and 3 legumes). The number of species in mixtures M2 (4 species), M8 (7 species) and M5 (5 species) has not determined significant yield differences for the first year (Tab. 1). Similar results were obtained by other studies (Skinner et al., 2006), with insignificant differences for DM yields between two mixtures of 3 , respectively 11 species. The M7 mixture yield was bigger than the yields of the other mixtures.

The influence of the interaction between the two experimental factors (mixture and fertilization) on dry matter yield is presented in Tab. 2. Different fertilization doses have not determined significant yield differences on the M7 mixture variants, where the best yields were obtained. The joint influence of the two factors sets the M5 mixture apart from the M2 mixture, favouring the latter. The M2 mixture has provided superior dry matter yields when compared to the M5 mixture, for all fertilization levels, while yield increases were also significant.

Using the same fertilization dose, M8 recorded significant higher yield than M5 mixture. Similarly, it should be noted that the yield of M5 with maximum fertilization dose was inferior to fodder yields obtained from the M8 mixture for the F1 and F2 fertilization levels, but differences were insignificant.

Tab. 1. The influence of mixture on DM yields $\left(\mathrm{t} \cdot h \mathrm{a}^{-1}\right)$

\begin{tabular}{ccc}
\hline Mixture & DM yield $\left(\mathrm{t} \cdot \mathrm{ha}^{-1}\right)$ & \multirow{2}{*}{ TSD $\mathrm{p}=0.05$} \\
${$\cline { 1 - 2 }$} }$ & $10.42 \mathrm{a}$ & 1.32 \\
M6 & $10.43 \mathrm{a}$ & 1.38 \\
M3 & $11.10 \mathrm{ab}$ & 1.43 \\
M4 & $11.22 \mathrm{ab}$ & 1.45 \\
M9 & $12.44 \mathrm{~b}$ & 1.47 \\
M5 & $13.88 \mathrm{c}$ & 1.49 \\
M8 & $14.94 \mathrm{c}$ & 1.50 \\
M2 & $15.19 \mathrm{c}$ & 1.50 \\
\hline M7 & $17.48 \mathrm{~d}$ & \\
\hline
\end{tabular}

Values followed by the same letters do not significantly differ at $\mathrm{P} \leq 0.05$, according to the Duncan's test 
Tab. 2. The influence of the mixture-fertilization interaction on DM yields $\left(\mathrm{t} \cdot \mathrm{ha}^{-1}\right)$

\begin{tabular}{|c|c|c|c|c|c|}
\hline $\begin{array}{c}\text { Mixture } \\
(\mathrm{M}) / \\
\text { Fertilization } \\
(\mathrm{F})\end{array}$ & $\begin{array}{c}\text { DM yield } \\
\left(\mathrm{t} \cdot \mathrm{ha}^{-1}\right)\end{array}$ & $\begin{array}{c}\text { TSD } \\
\mathrm{p}=0.05\end{array}$ & $\begin{array}{c}\text { Mixture } \\
(\mathrm{M}) / \\
\text { Fertilization } \\
(\mathrm{F})\end{array}$ & $\begin{array}{c}\text { DM yield } \\
\left(\mathrm{t} \cdot \mathrm{ha}^{-1}\right)\end{array}$ & $\begin{array}{c}\text { TSD } \\
\mathrm{p}=0.05\end{array}$ \\
\hline M1F1 & $9.87 \mathrm{a}$ & - & M9F3 & $12.66 \mathrm{f}$ & 0.70 \\
\hline M6F1 & $9.88 \mathrm{a}$ & 0.58 & M5F1 & $13.6 \mathrm{~g}$ & 0.70 \\
\hline M3F1 & $10.36 \mathrm{ab}$ & 0.62 & M5F2 & $13.8 \mathrm{gh}$ & 0.70 \\
\hline M6F2 & $10.42 \mathrm{ab}$ & 0.63 & M5F3 & $14.23 \mathrm{hi}$ & 0.70 \\
\hline M1F2 & $10.44 \mathrm{ab}$ & 0.65 & M8F1 & $14.61 \mathrm{ij}$ & 0.70 \\
\hline M4F1 & $10.54 \mathrm{~b}$ & 0.66 & M8F2 & $14.81 \mathrm{ijk}$ & 0.71 \\
\hline M1F3 & $10.93 b c$ & 0.67 & $\mathrm{M} 2 \mathrm{~F} 1$ & $14.99 \mathrm{jk}$ & 0.71 \\
\hline M6F3 & $10.98 \mathrm{bc}$ & 0.67 & $\mathrm{M} 2 \mathrm{~F} 2$ & $15.14 \mathrm{jk}$ & 0.71 \\
\hline M3F2 & $11.37 \mathrm{~cd}$ & 0.68 & M8F3 & $15.39 \mathrm{k}$ & 0.71 \\
\hline M4F2 & $11.38 \mathrm{~cd}$ & 0.68 & $\mathrm{M} 2 \mathrm{~F} 3$ & $15.44 \mathrm{k}$ & 0.71 \\
\hline M3F3 & $11.57 \mathrm{cde}$ & 0.69 & M7F2 & $17.30 \mathrm{l}$ & 0.71 \\
\hline M4F3 & $11.72 \mathrm{de}$ & 0.69 & M7F3 & 17.471 & 0.71 \\
\hline M9F1 & $12.14 \mathrm{ef}$ & 0.69 & M7F1 & 17.661 & 0.71 \\
\hline M9F2 & $12.51 \mathrm{f}$ & 0.70 & & & \\
\hline
\end{tabular}

F1-0NOP ${ }_{2} \mathrm{O}_{5} \mathrm{~kg} \cdot \mathrm{ha}^{-1} ; \mathrm{F} 2-60 \mathrm{~N} 70 \mathrm{P}_{2} \mathrm{O}_{5} \mathrm{~kg} \cdot \mathrm{ha}^{-1} ; \mathrm{F} 3-120 \mathrm{~N} 70 \mathrm{P}_{2} \mathrm{O}_{5} \mathrm{~kg} \cdot \mathrm{ha}^{-1}$
The results of the botanical composition analysis for the $3^{\text {rd }}$ cutting (Tab. 3 ) indicate that in 7 out of the 8 mixtures, the legumes ratio was higher or equal to the ratio of the sowing mixtures. A strong increase of the legumes ratio against their ratio in the sowing mixture was noticeable in such mixtures as M8 (M8F1 86.5\%, M8F2 76.6\%, M8F3 $95.0 \%$ compared to $22 \%$ on sowing), M5 (M5F1 66.2\%, M5F2 $61.3 \%$, M5F3 $46.2 \%$ compared to $15 \%$ on sowing) and M7 (M7F1 90.5\%, M7F2 97.2\%, M7F3 96.0\% compared to $30 \%$ on sowing), while the smallest ratio was recorded in the M3 mixture variants (M3F1 24.1\%, M3F2 $7.4 \%$, M3F3 $29.4 \%$ compared to $47 \%$ on sowing). Such an evolution of legumes in the M3 mixture could be a result of certain biologic traits, as the low competition ability and the low regrowth of species such as $O$. viciifolia and $L$. corniculatus, for the first year of vegetation (Liu et al., 2009; Motcă et al., 1994; Rotar and Carlier, 2005). The negative impact on $O$. viciifolia, determined by competition with $F$. pratensis was reported in the work of Liu et al. (2009). The competitive advantage shown by the F.pratensis species may be correlated with a more efficient water use for the first 6 months after sowing, as it is well know that one of the important factors for plant competition is water

Tab. 3. The influence of mixture and fertilization on the botanical composition of swards on the $3^{\text {rd }}$ cutting (\% from FM weight of sample)

\begin{tabular}{|c|c|c|c|c|c|c|}
\hline \multirow{2}{*}{$\begin{array}{l}\text { Mixture }(\mathrm{M}) / \\
\quad \text { Level of } \\
\text { fertilization }(\mathrm{F})\end{array}$} & \multirow{2}{*}{$\begin{array}{c}\text { Grasses } \\
\text { (\% from the } \\
\text { sowing rate) }\end{array}$} & \multirow{2}{*}{$\begin{array}{c}\text { Grasses } \\
\text { (\% from the FM } \\
\text { weight of sample) }\end{array}$} & \multirow{2}{*}{$\begin{array}{l}\text { Legumes } \\
\text { (\% from the } \\
\text { sowing rate) }\end{array}$} & \multirow{2}{*}{$\begin{array}{c}\text { Legumes } \\
\text { (\% from the FM } \\
\text { weight of sample) }\end{array}$} & \multicolumn{2}{|c|}{$\begin{array}{c}\text { Weeds } \\
\text { (\% from the FM weight of sample) }\end{array}$} \\
\hline & & & & & Monocots & Dicots \\
\hline M1F1 & \multirow{3}{*}{ - } & 0.0 & \multirow{3}{*}{100} & 7.2 & 88.3 & 4.5 \\
\hline M1F2 & & 0.0 & & 14.4 & 62.7 & 22.9 \\
\hline M1F3 & & 0.0 & & 13.0 & 67.7 & 19.3 \\
\hline $\mathrm{M} 2 \mathrm{~F} 1$ & \multirow{3}{*}{40} & 38.5 & \multirow{3}{*}{60} & 60.0 & 0,0 & 1.5 \\
\hline $\mathrm{M} 2 \mathrm{~F} 2$ & & 28.7 & & 61.2 & 4.1 & 6.0 \\
\hline $\mathrm{M} 2 \mathrm{~F} 3$ & & 29.8 & & 63.6 & 6.6 & 0.0 \\
\hline M3F1 & \multirow{3}{*}{53} & 67.4 & \multirow{3}{*}{47} & 24.1 & 1.1 & 7.4 \\
\hline M3F2 & & 80.6 & & 7.4 & 5.7 & 6.3 \\
\hline M3F3 & & 42.6 & & 29.4 & 12.7 & 15.3 \\
\hline M4F1 & \multirow{3}{*}{70} & 9.6 & \multirow{3}{*}{30} & 37.6 & 35.6 & 17.2 \\
\hline M4F2 & & 50.5 & & 41.0 & 5.9 & 2.6 \\
\hline M4F3 & & 19.6 & & 40.8 & 29.1 & 10.5 \\
\hline M5F1 & \multirow{3}{*}{85} & 32.5 & \multirow{3}{*}{15} & 66.2 & 0.0 & 1.3 \\
\hline M5F2 & & 36.7 & & 61.3 & 0.0 & 2.0 \\
\hline M5F3 & & 43.9 & & 46.2 & 7.9 & 2.0 \\
\hline M6F1 & \multirow{3}{*}{85} & 40.6 & \multirow{3}{*}{15} & 18.1 & 38.4 & 2.9 \\
\hline M6F2 & & 45.9 & & 18.8 & 30.7 & 4.6 \\
\hline M6F3 & & 27.9 & & 35.8 & 14.0 & 22.3 \\
\hline M7F1 & \multirow{3}{*}{70} & 9.5 & \multirow{3}{*}{30} & 90.5 & 0.0 & 0.0 \\
\hline M7F2 & & 2.6 & & 97.2 & 0.0 & 0.2 \\
\hline M7F3 & & 4.0 & & 96.0 & 0.0 & 0.0 \\
\hline M8F1 & \multirow{3}{*}{78} & 10.9 & \multirow{3}{*}{22} & 86.5 & 2.6 & 0.0 \\
\hline M8F2 & & 22.9 & & 76.6 & 0.0 & 0.5 \\
\hline M8F3 & & 4.6 & & 95.0 & 0.4 & 0.0 \\
\hline M9F1 & \multirow{3}{*}{76} & 61.1 & \multirow{3}{*}{24} & 35.4 & 3.5 & 0.0 \\
\hline M9F2 & & 48.5 & & 24.0 & 25.0 & 2.5 \\
\hline M9F3 & & 46.6 & & 34.1 & 12.5 & 6.8 \\
\hline
\end{tabular}

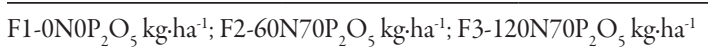


38

(Hopkins, 2003). This hypothesis relies on the values of the $\Delta^{13} \mathrm{C}$ of the two fertilization levels applied to this species (Tab. 5). A similar legume ratio to the initial sowing one was recorded for the M2 mixtures (M2F1 60.0\%, M2F2 $61.2 \%$, M2F3 $63.6 \%$ compared to $60 \%$ on sowing) for all the three fertilization doses. In the sward of experimental variants at the $3^{\text {rd }}$ cutting, it was shown that the highest weeds ratio occurs in the case of the alfalfa pure crop, for all three fertilization levels, while the monocots-grasses were dominant. These weeds strongly compete with the alfalfa crop during the first year of vegetation, a fact observed by other researchers as well (Mathieu, 2003). Furthermore, a bigger ratio of weeds in the alfalfa monoculture compared to the alfalfa crop in mixtures with grasses is signaled by the results of other specialists (Spandl et al., 1997). The lowest weed presence at $3^{\text {rd }}$ cutting was observed for the M7 mixture (of 6 species). Monocot weeds were absent in all three fertilization levels, while dicot weeds were solely present in one variant (M7F2), where their ratio was nevertheless small (0.2\%). Throughout the whole experiment, the monocot weeds exhibited the largest ratio. Yields provided by complex mixtures and showing great competition capacity with weeds shed light on the benefits of polycultures (Picasso et al., 2008).

A more judicious differentiation of mixtures and the assessment of fodder quality (Abe, 2007; Skladanka et al., 2008) included an analysis of protein content, as well as cell wall constituents (NDF, ADF, ADL). The NDF refers to the total cell wall constituents, composed of the ADF fraction plus hemicellulose (Carlier et al., 1998; Carlier and Vlahova, 1995). The ADF values are important because they describe the ability of an animal to digest the forage. As the ADF increases, the digestibility of the forage usually decreases (Carlier et al., 1998). Neutral detergent fiber values are important in ration formulation because they reflect the amount of forage that the animal can consume (Albayrak et al., 2011).

Analysis of the selected fodder plants quality parameters showed that, out of the two mixtures that recorded the highest yields (M7 and M2), the highest protein content was reported in the case of the M2 mixture (19.69\%)

Tab. 4 . The influence of mixture and fertilization on the fodder selected quality parameters (\% of DM)

\begin{tabular}{|c|c|c|c|c|c|}
\hline Mixture & $\begin{array}{l}\text { Level of } \\
\text { fertilization } \\
(\mathrm{F})\end{array}$ & $\begin{array}{c}\mathrm{CP} \\
\%\end{array}$ & $\begin{array}{l}\text { NDF } \\
\%\end{array}$ & $\begin{array}{c}\mathrm{ADF} \\
\%\end{array}$ & $\begin{array}{c}\mathrm{ADL} \\
\%\end{array}$ \\
\hline M2. Medicago sativa L., & $\mathrm{F} 1$ & 19.66 & 51.22 & 34.54 & 4.44 \\
\hline $\begin{array}{l}\text { Trifolium alexandrinum L., } \\
\text { Dactylis glomerata L., }\end{array}$ & $\mathrm{F} 2$ & 18.60 & 50.84 & 34.67 & 4.49 \\
\hline Lolium $x$ hybridum Hausskn. & F3 & 19.69 & 51.78 & 35.58 & 4.78 \\
\hline $\begin{array}{l}\text { M7. Trifolium pratense L., } \\
\text { Lotus corniculatus L., }\end{array}$ & $\mathrm{F} 1$ & 17.39 & 49.12 & 34.36 & 4.86 \\
\hline $\begin{array}{l}\text { Trifolium alexandrinum L., } \\
\text { Dactylis glomerata L., } \\
\text { Festuca pratensis Huds., }\end{array}$ & F2 & 19.02 & 48.47 & 31.71 & 4.21 \\
\hline Lolium $x$ hybridum Hausskn. & F3 & 18.27 & 48.76 & 34.00 & 4.60 \\
\hline
\end{tabular}

under the maximum nitrogen fertilization dose $(120 \mathrm{~kg}$ $\mathrm{N} \cdot \mathrm{ha}^{-1}$ ) (Tab. 4). The highest fodder protein content for the M7 mixture (19.02\%) was reported in the case of the $60 \mathrm{~kg} \mathrm{~N} \cdot \mathrm{ha}^{-1}$ dose. However, it must be observed that, in comparison to the M7 mixture, for M2, the fodder shows the highest content for cell wall constituents, both NDF (M2F1 51.22\%, M2F2 50.84\% and M2F3 51.78\%), and ADF (M2F1 34.54, M2F2 34.67 and M2F3 35.58\%) for all three fertilization doses. The lower fodder content for NDF and ADF in the M7 mixture may be due to the higher ratio of legumes in the sward of each variant, compared to the same variants of the M2 mixture, where grasses predominate. Legume stalks exhibit a more obvious increase of the cell wall concentration as they grow, compared to the increase within the leaves. Unlike legumes, grasses exhibit an obvious increase of the cell wall deposits in stalks, as well as leaves, during growth (Hatfield et al., 2007). For the same level of $\mathrm{N}$ fertilization, the lignin fodder content (ADL) from the M7 mixture (M7F2 4.21\% and M7F3 $4.60 \%$ ) was lower compared to the one in the M2 mixture (M2F2 4.49\% and M2F3 4.78\%).

Upon the selection of fodder species for pastures, respectively genotypes within species, alongside such characteristics as yield and fodder value, one should consider their ability to efficiently use water. WUE represents an important performance indicator for sustainability in specialized dairy farms (Neal et al., 2011). The selection of perennial fodder species with $\mathrm{C} 3$ photosynthesis able to efficiently employ water in limiting conditions may be conducted on the basis of information provided by $\Delta^{13} \mathrm{C}$ determinations (Lelievre et al., 2011). The applicability of this solution in particular for C3 plants (Condon et al., 2006) is supported by the fact that the variations of the isotope composition for ${ }^{13} \mathrm{C}$ are higher in $\mathrm{C} 3$ than in $\mathrm{C} 4$ plants, while the dependency between $\Delta^{13} \mathrm{C}$ and the $p_{i} / p_{a}$ ratio for $\mathrm{C} 3$ plants is linear and maximal. Consequently, experimental results obtained will be presented for carbon isotope discrimination and the ratio of partial pressures $\left(p_{i} / p_{a}\right)$ of $\mathrm{CO}_{2}$ in intercellular spaces $\left(p_{i}\right)$ of leaves and the atmosphere $\left(p_{a}\right)$ for species in the M7 and M2 mixtures, which provided the highest DM yields. This assessment was conducted 6 months after sowing. Once the intercellular pressure of the analyzed leaves was determined, a relation between it and fertilization was required to be established. Relying on mass spectrometry analyses, the $\delta^{13} \mathrm{C}$ isotope composition was determined from the leaves of the pure crop species (Tab. 5).

The $\delta^{13} \mathrm{C}$ values were typical values for $\mathrm{C} 3$ species and ranged between $-24.2 \%$ ( $F$. pratensis $120 \mathrm{~N}^{2} 0 \mathrm{P}_{2} \mathrm{O}_{5}$ ) and $-29.4 \%$ ( $L$. corniculatus $\left.0 \mathrm{NOP}_{2} \mathrm{O}_{5}\right)$. The values calculated for $\Delta^{13} \mathrm{C}$ and $p_{i} / p_{a}$ ratio for the analyzed species (Tab. 5) varied between $16.2 \%$ o $\left(\Delta^{13} \mathrm{C}\right.$ for $F$. pratensis

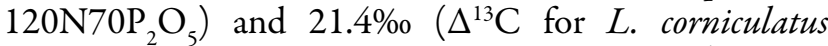
$\left.0 \mathrm{~N} 0 \mathrm{P}_{2} \mathrm{O}_{5}\right)$, respectively between $0.463395 \mathrm{ppm}\left(p_{i} / p_{a}\right.$ for $F$. pratensis $\left.120 \mathrm{~N} 70 \mathrm{P}_{2} \mathrm{O}_{5}\right)$ and $0.667748 \mathrm{ppm}\left(p_{i} / p_{a}\right.$ for $L$. corniculatus $0 \mathrm{~N}_{0} \mathrm{P}_{2} \mathrm{O}_{5}$ ). A linear and positive relationship 
Tab. 5. Isotope composition $\left(\delta^{13} \mathrm{C}\right)$, isotope discrimination $\left(\Delta^{13} \mathrm{C}\right)$ and $p_{i} / p_{a}$ values for species within M2 and M7 mixtures (C3 species) and their selection use

\begin{tabular}{|c|c|c|c|}
\hline Species/Fertilization & $\begin{array}{c}\delta^{13} \mathrm{C}_{\mathrm{vsPB}} \pm \mathrm{U}_{\mathrm{C}} \\
(\mathrm{k}=2)\end{array}$ & $\Delta(\%)$ & $p_{i} / p_{a}$ \\
\hline $\begin{array}{l}\text { Medicago sativa } \\
0 \mathrm{NOP}_{2} \mathrm{O}_{5}\end{array}$ & $-28.416 \pm 0,3$ & 20.416 & 0.628243 \\
\hline $\begin{array}{l}\text { Medicago sativa } \\
120 \mathrm{~N} 70 \mathrm{P}_{2} \mathrm{O}_{5}\end{array}$ & $-29.314 \pm 0,3$ & 21.314 & 0.663472 \\
\hline $\begin{array}{l}\text { Dactylis glomerata } \\
0 \mathrm{NOP}_{2} \mathrm{O}_{5}\end{array}$ & $-24.945 \pm 0,3$ & 16.945 & 0.492073 \\
\hline $\begin{array}{l}\text { Dactylis glomerata } \\
120 \mathrm{~N} 70 \mathrm{P}_{2} \mathrm{O}_{5}\end{array}$ & $-24.657 \pm 0,3$ & 16.657 & 0.480775 \\
\hline $\begin{array}{l}\text { Lotus corniculatus } \\
0 \mathrm{NOP}_{2} \mathrm{O}_{5}\end{array}$ & $-29.423 \pm 0,3$ & 21.423 & 0.667748 \\
\hline $\begin{array}{l}\text { Lotus corniculatus } \\
120 \mathrm{~N} 0 \mathrm{P}_{2} \mathrm{O}_{5}\end{array}$ & $-29.204 \pm 0,3$ & 21.204 & 0.659157 \\
\hline $\begin{array}{l}\text { Festuca pratensis } \\
0 \mathrm{NOP}_{2} \mathrm{O}_{5}\end{array}$ & $-27.584 \pm 0,3$ & 19.584 & 0.595603 \\
\hline $\begin{array}{l}\text { Festuca pratensis } \\
120 \mathrm{~N} 0 \mathrm{P}_{2} \mathrm{O}_{5}\end{array}$ & $-24.214 \pm 0,3$ & 16.214 & 0.463395 \\
\hline $\begin{array}{l}\text { Trifolium pratense } \\
0 \mathrm{NOP}_{2} \mathrm{O}_{5}\end{array}$ & $-28.703 \pm 0,3$ & 20.703 & 0.639502 \\
\hline $\begin{array}{l}\text { Trifolium pratense } \\
120 \mathrm{~N} 0 \mathrm{P}_{2} \mathrm{O}_{5}\end{array}$ & $-28.249 \pm 0,3$ & 20.249 & 0.621692 \\
\hline $\begin{array}{l}\text { Trifolium alexandrinum } \\
0 \mathrm{NO}_{2} \mathrm{O}_{5}\end{array}$ & $-28.831 \pm 0,3$ & 20.831 & 0.644524 \\
\hline $\begin{array}{l}\text { Trifolium alexandrinum } \\
120 \mathrm{~N}_{70 \mathrm{P}_{2}} \mathrm{O}_{5}\end{array}$ & $-28.723 \pm 0,3$ & 20.723 & 0.640287 \\
\hline $\begin{array}{l}\text { Lolium hybridum } \\
0 \mathrm{~N} 0 \mathrm{P}_{2} \mathrm{O}_{5}\end{array}$ & $-27.323 \pm 0,3$ & 19.323 & 0.585364 \\
\hline $\begin{array}{l}\text { Lolium bybridum } \\
120 \mathrm{~N} 70 \mathrm{P}_{2} \mathrm{O}_{5}\end{array}$ & $-27.615 \pm 0,3$ & 19.615 & 0.596819 \\
\hline
\end{tabular}

was determined between the $\Delta^{13} \mathrm{C}$ and $p_{i} / p_{a}$ for the species under analysis (Tab. 5). The $p_{i} / p_{a}$ ratio is determined by the balance between the photosynthetic capacity of the plant and stomatal conductance. Additionally, a small value of the $p_{i} / p_{a}$ ratio may be determined by low stomatal conductance, as well as by high photosynthetic capacity or by both. Drought and phosphorus deficit in soil determine the decrease of photosynthesis rate and stomatal conductance in plant shoots, thus restricting plant growth (Suriyagoda $e t$ al., 2011). The analyses of the $p_{i} / p_{a}$ ratio of the plants of the two analyzed mixtures (M2 and M7) revealed that, within the given experimental conditions and based on one year-long field trial, for the genotypes of $M$. sativa and Lolium $x$ hybridum species used in the experiment, the $p_{i} / p_{a}$ and $\Delta^{13} \mathrm{C}$ values increased as the fertilization dose increased. Such an evolution for these species provides them with minimal chances to increase their values for the WUE parameter. A similar evolution with respect to the increase of the DM yield in $M$. sativa once the $\Delta^{13} \mathrm{C}$ value increased (6 months after sowing) and thus with minimal chances to increase the WUE value, was also depicted by De Oliveira et al. (2003). For the other species within the two mixtures (Trifolium pratense, Lotus corniculatus, Trifolium alexandrinum, Dactylis glomerata, Festuca pratensis) the $p_{i} / p_{a}$ decreased as fertilization doses increased. The values obtained for the partial pressure ratio for these last species mentioned increase once $\Delta^{13} \mathrm{C}$ increases and decrease as the fertilization dose increases. The others research results indicated that a low value of isotope discrimination for C3 plants was correlated with a high water use efficiency (Condon et al., 2006). In accordance with such conclusions and relying on results obtained for the five species (Trifolium pratense, Lotus corniculatus, Trifolium alexandrinum, Dactylis glomerata, Festuca pratensis) where a negative connection was observed between fertilization and $\Delta^{13} \mathrm{C}$, one can possible consider a more efficient water use by these species. The $p_{i} / p_{a}$ values for legumes as Trifolium pratense, Lotus corniculatus and Trifolium alexandrinum are higher than in the case of such grasses as Dactylis glomerata and Festuca pratensis. The higher $p_{i} / p_{a}$ values for these legumes indicate a competitive advantage against grasses, possible due to legume radicular exudates. These exudates favour phosphorus availability for these species, as well as the hydraulic continuity between root and soil during drought (Suriyagoda et al., 2011). Relying on these observations and considering the conclusions of other researchers (Neal et al., 2011) that indicate the existence of a strong positive correlation between species yield and WUE, it becomes apparent that the proportion of legumes in the mixture is highly important.

\section{Conclusions}

This study presents a comprehensive analysis of agronomic information and carbon isotope discrimination $\left(\Delta^{13} \mathrm{C}\right)$ for perennial fodder species in complex mixtures of perennial fodder plants for temporary pastures in the Transylvanian Plain. Mixture M7 displayed the highest yield, highest ratio of legumes in the sward and highest competitiveness against weeds. The relationship between fertilization, $\Delta \Delta^{13} \mathrm{C}$ determination and the $p_{i} / p_{a}$ ratio for the component species of the M7 mixture indicated that five out of the six species exhibit high susceptibility for efficient water use. Based on obtained results the new created M7 mixture can be considered as a good solution for fodder production in Transylvanian area. $\Delta^{13} \mathrm{C}$ for perennial fodder plants in selecting the species for temporary pastures alongside agronomic information should be a priority in the selection of most efficient species

\section{Acknowledgments}

This work was supported by the National Council for Higher Education Scientific Research (CNCSIS), the Executive Unit for the Financing of Higher Education and Academic Scientific Research (UEFISCSU), Romania, project PNII-IDEI, nr. 1107, CNCSIS code 1488/2008. 
40

\section{References}

Abe A (2007). Estimation of nutritive value and dry matter intake of forage. Animal Sc J 78(3):211-217.

Albayrak S, Türk M, Yüksel O, Yilmaz M (2011). Forage yield and the quality of perennial legume-grass mixtures under rainfed conditions. Not Bot Horti Agrobo 39(1):114-118.

Beranger C (2002). La multifunctionnalité des prairies: les acquis et les interrogations de $19^{\text {emme }}$ Congrés Européen des Herbages. Fourrages 171:227-237.

Brugnoli E, Farquhar GD (1995). Photosynthetic fractionation of carbon isotopes, 399-434 p. In: Leegood R, Sharkey C, Von Caemmerer S (Eds.). Photosynthesis: physiology and metabolism. Kluwer Acad. Publishers, Netherlands.

Carlier L, Vlahova M (1995). Improvement and evaluation of the quality of forage crops. Biotechnol Biotechnolog Equip 9(2):3-14.

Carlier L, Puia I, Rotar I (1998). For a better grass production. Ed. Risoprint. Cluj-Napoca, 90-120 p.

Carlier L, Rotar I, Vlahova M, Vidican R (2009). Importance and functions of grasslands. Not Bot Horti Agrobo 37(1):25-30.

Ciocârlan V (2000). Illustrated flora of Romania. Pteridophyta and Spermatophyta. Ed. Ceres, Bucharest.

Coleman DC (1991). Carbon isotope techniques. Academic Press Inc., San Diego, 187-200 p.

Commission of the European Communities(2009).Commission staff working document: The role of European agriculture in climate change mitigation. Brussels, 23.07.2009.

Condon AG, Farquhar GH, Rebetzeke GJ, Richards RA (2006). Drought adaptation in cereals, 171-219 p. In: Ribaut J-M (Ed). The application of carbon isotope discrimination in cereal improvement for water-limited environments. Food Product Press.

Connolly J, Finn JA, Black AD, Kirwan L, Brophy C, Lüscher A (2009). Effects of multi-species swards on dry matter production and the incidence of unsown species at three Irish sites. Irish J Agricult Food Res 48:243-260.

De Oliveira WS, Oliveira PPA, Corsi M, Trivelin PCO, Tsai SM (2003). Water availability on yield and nitrogen contents of alfalfa (Medicago sativa L.). Rev Bras Zoo-Braz J Animal Sci 32(6):1275-1286.

Farineau J, Morot-Gaudry J-F (2006). La photosynthèse. Processus physiques, moléculaires et physiologiques. Metabolismes de types C4 et CAM. Collection Synthèses. INRA Paris, 293-314 p.

Farquhar GD, O'Leary MH, Berry JA (1982). On the relationship between carbon isotope discrimination and the intercellular carbon dioxide concentration in leaves. Austr J Plant Physiol 9(2):121-137.

Grieu P, Lucero DW, Ardiani R, Ehleringer JR (2001). The mean depth of soil water uptake by two temperate grassland species over time subjected to mild soil water deficit and competitive association. Plant Soil 230:197-209.

Hatfield RD, Jung HJG, Broderick G, Jenkins TC (2007). Nutritional chemistry of forages, 467-486 p. In: Barnes RF, Nelson CJ, Moore KJ, Collins M (Eds.). Forages The Science of Grassland Agriculture. $6^{\text {th }}$ edition. Blackwell Publishing. Ames, Iowa, USA.

Hopkins WG (2003). Physiologie végétale. Ed. De Boeck Université. Bruxelles. Imprimé en Espagne.

Hopkins A, Del Prado A (2007). Implications of climate change for grassland in Europe: impacts, adaptations and mitigation options. Grass Forage Sci 62(2):118-126.

Lehmann B, Hediger W (2004). The contribution of grassland to social benefits of agriculture-an economic analysis. Proceedings of the $20^{\text {nd }}$ General Meeting of the European Grassland Federation 9:105-116.

Lelievre FG, Ledda SL, Porqueddu C, Volaire F (2011). Water use efficiency and drought survival in Mediterranean perennial forage grasses. Field Crops Res 121(3):333-342.

Liu Z, Baines RN, Lane GPF, Davies WP (2009). Survival of plants of common sainfoin (Onobrychis viciifolia Scop.) in competition with two companion grass species. Grass Forage Sci 65:11-14.

Mathieu M (2003). Luzerne-culture, recolte, conservation, utilisation. Editions France Agricole, 11-68 p.

Ministry of Agriculture and Rural Development Romania (2008). National strategy for mitigation of drought effects, prevention and control of lands degradation and desertification on short, medium and long term (in Romanian).

Mosimann E, Suter D, Rosenberg E (2008). Mélanges standard pour la production fourragère 2009-2012. Revue Suisse Agric 40(5):1-12.

Motcă Gh, Oancea I, Geamănu L-I (1994). Pastures of Romania. Typology and technology. Tehnică Agricolă Ed., Bucharest, 97-150 p (in Romanian).

Neal JS, Fulkerson WJ, Sutton BG (2011). Differences in wateruse efficiency among perennial forages used by the dairy industry under optimum and deficit irrigation. Irrig Sci 29:213-232.

Nyfeler D, Huguenin-Elie O, Suter M, Frossard E, Connolly J, Lüscher A (2009). Strong mixture effects among four species in fertilized agricultural grassland led to persistent and consistent transgressive overyielding. J Appl Ecol 46:683691.

Pannecoucque J, Van Waes J, De Vliegher A, Herman JL (2011). Catalogue belge-description et recommandation. Plantes fourragères et engrais verts. Instituut vor landbouw en visserijonderzoek. Mededeling ILVO, $81 \mathrm{p}$.

Picasso VD, Brummer EC, Liebman M, Dixon PM, Wilsey BJ (2008). Crop species diversity affects productivity and weed suppression in perennial polycultures under two management strategies. Crop Sci 48(1):331-342.

Rotar I, Carlier L (2005). Pasture culture. Risoprint Ed. ClujNapoca, $177-218$ p. 
Skinner RH, David GL, Sanderson MA (2004). Growth, water relations, and nutritive value of pasture species mixtures under moisture stress. Crop Sc 44(4):1361-1369.

Skinner RH, Sanderson MA, Tracy BF, Dell CJ (2006). Aboveand belowground productivity and soil carbon dynamics of pasture mixtures. Agronom J 98(2):320-326.

Skladanka J, Dohnal V, Jezkova A (2008). Fibre and ergosterol contents in forage of Arrhenatherum elatius, Dactylis glomerata and Festulolium at the end of the growing season. Czech J Animal Sci 53(8):320-329.

Spandl E, Kells JJ, Hesterman OB (1997). Weed invasion in established alfalfa (Medicago sativa) seeded with perennial forage grasses. Weed Technol 11(3):556-560.

Surault F, Veron R, Chataigner F, Huyghe C (2007). Comportement de prairies mono ou plurispécifiques en année à déficit hydrique marqué. Fourrages 192:507-510.
Suriyagoda LDB, Megan HR, Renton M, Lambers H (2011). Above-and below-ground interactions of grass and pasture legume species when grown together under drought and low phosphorus availability. Plant Soil 348(1-2):281-297.

United Nations Framework Convention on Climate Change (UNFCCC), United Nations. Art. 4. 1992.

Van Soest PJ (1982). Nutritional ecology of the ruminant: Ruminant metabolism, nutritional strategies, the cellulolytic fermentation and the chemistry of forages and plant fibers. $\mathrm{O}$ and B Books Publisher. Corvallis, OR.

Van Waes J, Chaves B, Marynissen B, De Vliegher A, Carlier L, Herman JL (2008). Catalogue belge-description et recommendation. Plantes fourragères et engrais verts. Instituut voor landbouw en visserijonderzoek. Mededeling ILVO 9-61 p.

http://www.fao.org/ag/AGP/AGPC/doc/Gbase/genussearch. htm. Grassland index. 